\title{
Tantangan Migrasi, Pengelolaan Remitansi, dan Kekerasan Terhadap Buruh Migran Perempuan Asal Lombok di Malaysia dan Arab Saudi
}

\author{
Saipul Hamdi ${ }^{1}$ \\ Universitas Mataram
}

\begin{abstract}
This article aims to understand the migration challenges faced by female migrant workers (TKW) from Lombok who have worked in Saudi Arabia and Malaysia. The challenges faced by female migrant workers are complex, ranging from recruitment and shelter in the country of origin before leaving, and cultural and language issues in the workplace. This article explores these challenges and tries to relate them to the quality level of educational and human resources factors that prospective migrant workers have. Besides, this article also discusses the historical aspects of Sasak women's involvement and participation in migration and the factors that drove them to take up the profession as migrant workers. The issue of remittance management and violence faced by migrant workers in the employer's home becomes a crucial issue that requires serious attention from the government. Publicly speaking, female migrant workers continue to experience physical and sexual violence resulting in disability and severe trauma. Therefore, this article aims to investigate the forms of violence that befall the female migrant workers.
\end{abstract}

Keywords : Migrant Workers, Cultural Challenges, Remittance, Violence, Lombok

\begin{abstract}
Abstrak
Artikel ini bertujuan untuk memahami tantangan-tentangan migrasi yang dihadapi oleh buruh migran perempuan (TKW) asal Lombok yang pernah bekerja di Arab Saudi dan Malaysia. Tantangan yang dihadapi oleh buruh migran perempuan sangat kompleks mulai dari perekrutan dan penampungan di negara asal sebelum berangkat, persoalan kebudayaan dan bahasa di tempat kerja. Tantangan-tantangan inilah yang dieksplorasi dalam artikel ini dan mencoba mengaitkannya dengan faktor pendidikan dan SDM yang dimiliki oleh calon buruh migran. Selain itu artikel ini juga membahas tentang aspek historis atas keterlibatan dan partisipasi perempuan Sasak dalam dunia migrasi dan faktor-faktor yang mendorong mereka mengambil profesi sebagai buruh migran. Persoalan tentang pengelolaan remitansi dan kekerasan yang dihadapi oleh TKW di rumah majikan menjadi isu krusial yang membutuhkan perhatian serius dari pemerintah. Bukan rahasia publik TKW terus mengalami kekerasan fisik dan seksual yang mengakibatkan kecacatan dan trauma berat. Oleh karena itu, artikel ini bertujuan untuk menginvestigasi bentuk-bentuk kekerasan yang menimpa buruh migran perempuan tersebut.
\end{abstract}

Kata Kunci : Buruh Migran, Tantangan Kebudayaan, Remitansi, Kekerasan, Lombok

\footnotetext{
${ }^{1}$ shamdi@unram.ac.id
} 


\section{Pendahuluan}

Migrasi merupakan fenomena global yang terjadi sejak manusia menduduki bumi yang diperkirakan 1.7 juta tahun (Greenwood \& Hunt, 2003). Menurut catatan national geografik, migrasi manusia homo sapiens terjadi 70.000 tahun yang lalu dari Afrika ke Eurasia karena perubahakan iklim yang ekstrim. Proses migrasi disebabkan oleh berbagai faktor seperti bencana alam, kurangnya suplai makanan, perubahan iklim dan cuaca yang ekstrim dan krisis pekerjaan (Chin, 1997; Melchert, 2017; Silvey, 2004). Pada akhir abad pertengan migrasi di negara-nengara Eropa tidak terbendung ditandai dengan wabah dan perang antara etnis. Pada masa ini juga dikenal dengan masa discovery yakni penjelajahan ke wilayah luar Eropa yang diwarnai dengan kolonialisi dan invasi, bangsa Eropa menguasai setengah dari wilayah bumi (Pels, 2016; Scott, 1992). Selain mengambil alih kekuasaan di negara lain, mereka juga mengeruk sumber daya alam untuk kebutuhan ekonomi pemerintahan dan militer.

Jauh sebelum migrasi ke Malaysia dan negara-negara Timur Tengah, masyarakat Indonesia yang berada di bawah penjajah Belanda memberangkatkan para buruh migran dari Suku Jawa ke Suriname, salah satu negara jajahan Belanda yang terletak di Amerika Latin pada akhir abad ke 19 (Maksum \& Yogyakarta, 2017; Rahmat et al., 2018; Susanti, 2016). Pasca kemerdekaan presiden pertama Sukarno 1949 membuat kebijakan transmigrasi ke wilayah yang jarang penduduk termasuk Kalimantan, Sulawesi, Sumatera, dan Papua. Program transmigrasi ini dilanjutkan oleh Suharto secara massif dengan mengirim pekerja sebanyak 3 juta orang dari berbagai provinsi ke wilayah jarang penduduk melalui pembiayaian Asian Development Bank (ADB) (Putra, 2019). Dana ini digunakan untuk membangun perumahan sederhana dan biaya transportasi transimigran. Meskipun program transmigrasi menimbulkan berbagai persoalan seperti konflik sosial dengan warga lokal, ekspolitasi alam yang berlebihan, dan kerusakan lingkungan akibat pembukaan lahan baru, akan tetapi keberadaan mereka memberikan dampak positif khususnya pada pengembangan ekonomi, pendidikan dan pemerataan penduduk. 
Tantangan Migrasi, Pengelolaan Remitansi, dan Kekerasan Terhadap Buruh Migran Perempuan Asal Lombok di Malaysia dan Arab Saudi

Sejak 1980an masyarakat Indonesia bermigrasi ke Malaysia bekerja di area perkebunan kelapa sawit. Krisis moneter dan politik di tahun 1998 yang ditandai berakhirnya era Orde Baru telah menimbulkan gelombang besar migrasi buruh migran ke berbagai negara seperti Malaysia, Singapura, Hongkong, Taiwan, Korea Selatan dan negara-negara Timur Tengah. Selain di perkebunan kelapa sawit, buruh migran laki-laki (TKI) bekerja di infrastruktur, pabrik, dan tambang perminyakan. Sedangkan buruh migran perempuan (TKW) bekerja sebagai pembantu rumah tangga di rumah warga, babysitter, dan di restauran. Persoalan TKW jauh lebih kompleks dibanding TKI karena mereka tinggal di rumah keluarga yang sulit diakses oleh orang luar termasuk pemerintah, yang berdampak pada lemahnya proteksi kepada mereka. Praktik-praktik kekerasan terus mengalami reproduksi terhadap TKW oleh majikan, bahkan banyak yang berakhir mati tragis akibat penyiksaan. Artikel ini membahas tentang potret kehidupan eks buruh migran perempuan (TKW) asal Lombok yang pernah bekerja di Malaysia dan Arab Saudi.

TKW yang bekerja di luar negeri menjadi sorotan dunia internasional tidak hanya terkait jumlah angka TKW yang meningkat tajam, tetapi juga masalahmasalah yang mereka hadapi di tempat kerja yang tidak memperoleh perlindungan maksimal oleh negara asal maupun di negara tempat kerja (Chin, 1997). Mayoritas TKW bekerja di ruang domestik sebagai pembantu rumah tangga menghadapi berbagai isu krusial termasuk kekerasan fisik, verbal dan seksual, jam kerja yang berlebihan, pembatasan komunikasi, dan penudaan gaji. Persoalan-persoalan inilah yang membuat kehidupan TKW sangat rentan. Meskipun TKW dalam ancaman bahaya besar, akan tetapi jumlah TKW terus meningkat ke luar negeri. Oleh karena itu, artikel ini betujuan untuk mengeksplorasi sejarah dan faktor migrasi perempuan Sasak, tantangan yang dihadapi dan pola pengelolaan remitansi mereka oleh kerluaga. Selain itu artikel ini bertujuan untuk menginvestigasi bentuk-bentuk kekerasan yang terjadi pada mereka. 


\section{Metode Penelitian}

Penelitian ini dilakukan selama tiga tahun (2017-2019) di Lombok Nusa Tenggara Barat dengan pertimbangan bahwa masyarakat di pulau ini dikenal sebagai basis buruh migran. Propinsi NTB sendiri adalah distributor buruh migran terbesar kedua setelah Jawa Timur. Lombok merupakan wilayah agraris, akan tetapi masih berstatus tertinggal dengan penduduk di bawah garis kemiskinan mencapai 17.80\%. Perkembangan migrasi buruh migran di NTB sangat signifikan dan memainkan peran penting dalam pembangunan ekonomi keluarga dan peningkatan devisa daerah yang mencapai 1 triliun per tahun. Jumlah buruh migran pria dan wanita yang begitu besar tidak diikuti oleh pengembangan Sumber Daya Manusia mereka yang baik terbukti mayortitas buruh migran adalah lulusan SD dan SMP. Pada saat bersamaan mereka tidak memiliki skill dan pengetahuan yang cukup tentang bahasa dan budaya masyarakat di negara tempat mereka bekerja. Dampaknya, buruh migran asal Lombok rentan mengalami kekerasan fisik dan seksual, dan diskriminasi. Secara metodologis, penelitian ini menggunakan metode kualitatif dengan pendekatan etnografi. Data dikumpulkan melalui observasipartisipasi, in-depth interview, dan dokumentasi. Adapun informan yang telah diwawancarai tidak hanya dari buruh migran perempuan, tetapi juga laki-laki, keluarga, NGO yang konsen dengan buruh migran, PJTKI, Dinas Tenaga Kerja dan Transmigrasi, dan masyarakat umum. Analisa data menggunakan pendekatan fenomenologi yakni fokus melihat pengalaman-pengalaman yang dialami oleh para buruh migran khususnya migran perempuan selama di negara tempat bekerja dan pasca kembali ke daerah asal.

\section{Hasil dan Pembahasan}

\section{Dinamika Kehidupan dan Tantangan Buruh Migran}

Amarjit Kaur (2009: 276) melihat bahwa posisi Asia Tenggara sebagai salah satu destinasi favorit komunitas global karena kekayaan dan keindahan alamnya. Di akhir abad ke 19 dan awal abad ke 20 buruh migran asal India dan China berdatangan ke Asia Tenggara dan ini menunjukkan masa depan yang cerah atas globalisasi Asian. Migrasi Asian juga melibatkan komunitas migran 
Tantangan Migrasi, Pengelolaan Remitansi, dan Kekerasan Terhadap Buruh Migran Perempuan Asal Lombok di Malaysia dan Arab Saudi

transnasional orang-orang Eropa dan Amerika yang konsisten mengembangkan produksi ekspor dan industrialisiasi yang berdampak pada pertumbuhan ekonomi masyarakat lokal. Mereka mengeskplorasi kekayaan alam seperti gas, minyak, tambang emas, batu bara, dan kelapa sawit (lihat Kaur, 2009: 278; Larsen, 2010; 3). Serapan tenaga kerja yang cukup besar untuk memenuhi target produksi melahirkan perpaduan yang bagus antara buruh migran asing dan pekerja lokal (Wickramasekera, 2002: 9).

Ruang migrasi yang terbuka luas dan pemberian izin pembangunan perumahan kepada buruh migran menciptakan pluralitas dan hybrida kutural di mayarakat. Integrasi budaya dan sharing nilai keagamaan antara buruh migran dan masyarakat lokal menjadi bonus demografi bagi suatu daerah (Bahrin, 1967; Killias, 2010; Kaur, 2009; Silvey, 2007). Keberadaan mereka sebagai pendatang berpengaruh juga pada kemajuan di sektor edukasi, meskipun terkadang menimbulkan konflik karena kecemburuan sosial yang dilarabelakangi ketimpangan ekonomi antara pendatang dengan masyarakat lokal. Sejak tahun 1980, Asia Tenggara muncul sebagai pemain utama dalam gerakan migrasi global dengan diversitas dan perluasan yang terus meningkat secara tajam (Kaur, 2014; Kaur, 2009; Melchert, 2017; Silvey, 2004). Tujuan mereka yang pokok adalah pengembangan ekonomi sebagai titik balik pasca perang melawan kelompok kolonial. Negara-negara yang menjadi tujuan migrasi di Asia Tenggara adalah Malaysia, Singapura, Brunei dan Thailand. Jalur ilegal juga berkembang dalam proses migrasi dan menjadi salah satu tantangan negara-negara tujuan di Asia Tenggara untuk bekerja lebih keras mengontrol dan menjaga wilayah perbatasan maritime mereka (Killias, 2010; 900).

Arus migrasi tenaga kerja Indonesia ke luar negeri semakin meningkat jumlahnya. Banyak faktor yang menyebabkan derasnya arus migrasi, dan salah satunya disebabkan karena problem ketenagakerjaan di dalam negeri yang belum terpecahkan (Constable, 2009; Haryani et al., 2011; Killias, 2010). Krisis moneter yang berimplikasi pada ketidakstabilan ekonomi Indonesia pasca reformasi 1998 dan meningginya tingkat populasi karena kurang kontrol oleh masyarakat mendorong percepatan migrasi lintas gender dan usia (Sakdapolrak, 2002). 
Diperkirakan jumlah buruh migran Indonesia di luar negeri sebesar 4,5 juta orang tersebar di Malaysia, Singapura, Taiwan, Korea Selatan, Brunei serta negara-negara Timur Tengah (Asriani \& Amalia, 2014: 152). Sebagian besar di antara mereka adalah kaum perempuan yakni sekitar $70 \%$ bekerja di sektor domestik sebagai pembantu rumah tangga dan sebagian kecil bekerja di bagian manufaktur (Asriani \& Amalia 2014; Rahman \& Fee, 2009; Sulistiyo \& Wahyuni, 2012). Selebihnya sekitar $30 \%$ adalah buruh migran laki-laki bekerja di perkebunan, konstruksi, transportasi dan jasa (Maksum \& Surwandono, 2017; Rother \& Rother, 2017; Sulistiyo \& Wahyuni, 2012).

Buruh migran Indonesia memperoleh gaji antara Rp. 2.000.000-7.000.000 tergantung pekerjaannya. Gaji ini besarannya jauh dari standar gaji internasional (Human Wrights Watch, 2004; Silvey, 2004). Gaji tersebut lebih rendah dibandingkan dengan gaji buruh migran asal Filipina. Terlepas dari persoalan penggajian, persoalan pokok yang lain adalah minimnya perlindungan terhadap buruh migran, khususnya TKW yang selama ini rentan dengan kekerasan dan eksploitasi seksual majikan (Azmy, 2012; Bal \& Gerard, 2016; Human Wrights Watch, 2004). Meskipun tidak semua TKW mengalami nasib yang buruk, akan tetapi kasus yang ada menunjukkan grafik yang terus meningkat. Kasus TKW lebih kompleks karena keamanan, gaji, jam kerja dan masa libur yang tidak didapatkan (Asriani \& Amalia, 2014: 153; Bal \& Gerard, 2017: 4) . Kerentanan buruh migran sudah dialami sejak masa perekrutan di daerah asal oleh tekong. Proses ini merupakan awal dari mata rantai eksploitasi terhadap buruh migran Indonesia. Calo atau yang biasa disebut 'tekong' adalah perpanjangan tangan dari PJTKI yang merekrut langsung calon buruh migran di lapangan. Mereka keliling kampung mencari calon dengan informasi yang menggiurkan. Mereka menyasar masyarakat yang tidak terdidik dengan iming-iming gaji besar (Hermawan et al, 2014; Karim, 2017).

Tekong merupakan salah satu mata rantai yang menjadi titik persoalan buruh migran karena tidak profesional. Kegagalan calon buruh migran disebabkan kasus penipuan dan permainan antara agen dengan tekong. Saling lempar tanggung jawab antara tekong dengan PJTKI adalah alibi untuk menutupi penipuan mereka 
Tantangan Migrasi, Pengelolaan Remitansi, dan Kekerasan Terhadap Buruh Migran Perempuan Asal Lombok di Malaysia dan Arab Saudi

(Karim, 2017; Chin, 1997). Pemerintah seringkali mengutuk praktek percaloan sebagai sumber masalah buruh migran, akan tetapi mereka kesulitan melawan praktek gelap percaloan yang eksploitatif. Hampir sebagian besar buruh migran tidak bisa berangkat ke luar negeri karena ulah mereka. Oleh karena itu, proses perekrutan buruh migran sarat dengan praktek pemerasan dan penipuan. PJTKI berkontribusi besar terhadap eksistansi calo, karena merekalah tukang tadah dari hasil perekrutan para calo.

Pada masa bekerja sebagaian besar buruh migran bekerja disektor-sektor yang penuh resiko yang disebut 3D (dark, dirty, dangerous). Di negara Timur Tengah misalnya, TKW Indonesia yang menjadi korban pemerkosaan dan kekerasan fisik oleh majikan mencapai jumlah ribuan orang. Data resmi yang dari KBRI Arab Saudi dan KBRI Kuwait, jumlah buruh migran yang melarikan diri ke KBRI untuk mencari perlindungan dari tindak kekerasan dan perkosaan majikan mencapai sekitar 3.627 orang pertahun (Azmy, 2012). Puluhan mayat buruh migran Indonesia yang meninggal di Arab Saudi masih terlantar belum dikuburkan dan tidak bisa segera dikirim ke ahli waris Indonesia. Di Malaysia, buruh migran Indonesia diperlakukan sebagai 'persona non grata'. Politik anti migran pemerintah Malaysia merepresi buruh migran Indonesia yang tidak berdokumen (ilegal) di Malaysia (Killias 2010; Chin, 1997). Padahal sebelumnya merekalah yang menjadi tulang punggung perekonomian Malaysia. Untuk mengusir buruh migran Indonesia tak berdokumen, pemerintah Malaysia tidak hanya menerbitkan Akta Imigresen 1154 tahun 2002, tetapi juga melancarkan operasi yang mengerahkan tentara dan polisi Malaysia bersenjatakan lengkap menangkap buruh migran yang tidak lagi memiliki dokumen yang sah baik itu over stay maupun yang bersembunyi. Malaysia pun menggunakan milisi sipil RELA untuk menangkapi buruh migran Indonesia (Hakim \& Fitrianto, 2015).

Situasi status ilegal buruh migran seringkali dimanfaatkan oleh agen-agen yang tidak bertanggung jawab untuk praktek perdagangan perempuan dan juga perdagangan organ manusia. Tidak adanya perlindungan hukum menyebabkan buruh migran perempuan ke ruang gelap eksplotasi seksualitas (Larsen, 2010). Mereka diperdagangkan bekerja di bar, diskotik dan hiburan dunia malam. Tidak 
sedikit dari mereka juga bekerja sebagai Pekerja Seks Komersial (PSK) (Surtees, 2003: 102). Rina (45 tahun), salah satu buruh migran perempuan asal Lombok Tengah yang bekerja di Malasyia memilih profesi sebagai PSK melayani tamutamunya dari China, Hongkong dan orang Malaysia. Dia tidak memiliki banyak pilihan dan akhirnya berhenti setelah ibunya mendatanginya di dalam mimpi. Dia sadar bahwa di keluarganya tidak ada seorangpun yang melakukan praktek prostitusi. Dia merasa terhina dan berdosa, apalagi keluarganya dikenal soleh di masyarakat. Dia berusaha menyelamatkan diri ke Indonesia melalui pulau Batam dan menikah dengan orang Makassar.

\section{Perempuan Sasak di Arus Migrasi Indonesia}

Trend migrasi di Indonesia mengalami pergeseran yang cukup tajam, yang sebelumnya lebih banyak dikuasai oleh laki-laki. Sejak 2000an perempuan mulai aktif dan mengambil alih dominasi peran tersebut. Menurut data BNP2TKI, penempatan TKI di tahun 2011 sebanyak 586.802 orang, terdiri dari migran perempuan 376.686 (64 persen) dan migran laki-laki sebanyak 210.116 (36 persen). Tahun 2012 sebanyak 494.609 TKI, terdiri dari migran perempuan 279.784 (57 persen) dan migran laki-laki 214.825 (43 persen) (Lihat Asriani \& Amalia 2014: 154; Ardiansyah, 2007: 2-5). Tahun 2013 sebanyak 512.168 TKI, terdiri dari 276.998 TKW (54 persen) migran perempuan dan 235.170 TKL (46 persen) migran laki-laki. Tahun 2014 sebanyak 429.872 TKI, terdiri dari 243.629 TKW (57 persen) dan 186.243 TKL (43 persen). Provinsi Nusa Tenggara Barat dikenal sebagai salah satu daerah distributor TKI terbesar kedua Indonesia setelah Jawa Timur yakni 46.187 orang per tahun. Mayoritas TKI NTB adalah penduduk yang berdomisili di Lombok mencapai 44.500 orang, sisanya dari kepulauan Sumbawa 1.000 orang (BPS, NTB, 2018).

Pada awalnya yang menjadi buruh migran adalah kaum laki-laki yang kesulitan mengembangkan ekonomi keluarga, namun dalam perkembangannya buruh migran perempuan juga ambil bagian dengan berbagai macam alasan dan faktor. Fenomena buruh migran perempuan di Lombok NTB menunjukkan grafik yang terus meningkat sejak tahun 1996. Menurut data BPS Provinsi NTB bahwa pada tahun 2015 jumlah TKW mencapai angka 9.968 orang . Arus migrasi 
Tantangan Migrasi, Pengelolaan Remitansi, dan Kekerasan Terhadap Buruh Migran Perempuan Asal Lombok di Malaysia dan Arab Saudi

perempuan Sasak menjadi buruh migran adalah sejarah baru karena selama ini konstruksi budaya Sasak misalnya tidak memberikan ruang yang luas bagi kaum perempuan untuk bekerja di luar rumah dan tidak menjamin kebebasan mereka memilih pekerjaan yang disukainya. Jangakan bekerja di luar negeri, keluar kuliah di luar daerah mereka berjuang keras meyakinkan kedua orangtuanya. Oleh karena itu, menarik bagaimana melihat proses transformasi perempuan Sasak bekerja di luar negeri dan bagaimana kontribusinya di dalam pengembangan ekonomi keluarga.

Hidup di negara orang lain membutuhkan adaptasi baru mulai dari penguasaan bahasa, budaya dan juga penguasaan undang-undang negara. Para TKW seharusnya menguasai unsur-unsur tersebut sebelum berangkat ke negara tujuan sehingga tidak kesulitan dalam mengatasi berbagai persoalan seperti miskomunikasi. Namun kenyataannya, sebagian dari mereka tidak mau belajar dan nekat untuk berangkat tanpa dibekali dengan pengetahuan dan skil yang cukup. Sementara sebagian besar tekong-tekong TKI menyasar perempuan desa yang tidak memiliki sertifikat kerja dan kualifikasi pendidikan yang layak. Tingkat pendidikan para TKI dan TKW umumnya tidak sampai sarjana, bahkan lebih banyak tamatan SD, SMP dan SMA. Menurut BNP2TKI, dari angka penempatan TKI tahun 2014 sebanyak 429.872 orang, yang lulusan SD sebanyak 138.821 orang (32,29\%), lulusan SMP 162.731 orang (37,86\%), lulusan SMU 106.830 orang $(24,85 \%)$ persen, lulusan Diploma 17.355 orang (4,04\%), lulusan Sarjana 3.956 orang $(0,92 \%)$, dan lulusan pascasarjana 179 orang $(0,04 \%)$. Bahkan ada yang buta hurup tidak bisa membaca dan menulis, namun karena semangatnya mencari rezeki, dia berani berangkat keluar negeri menjadi buruh migran.

Keterbatasan pendidikan dan skil calon tenaga kerja Indonesia berdampak pada tidak banyaknya pilihan pekerjaan di luar negeri. Pilihan pekerjaan mereka pada umumnya adalah pembantu rumah tangga. Mayoritas TKW Indonesia berprofesi sebagai pembantu rumah tangga (PRT) dan hanya sebagian kecil yang bekerja di sektor jasa dan industri. Di antara negara-negara Asia Tenggara yang banyak menggunakan jasa PRT adalah Malaysia, Brunei Darussalam dan Singapura. Sedangkan di luar itu adalah negara-negara Timur Tengah seperti Arab 
Saudi, Kuwait, Yordania, Suriah, Qatar dan Uni Emirat Arab. Yang menarik adalah negara-negara yang menerima jasa PRT adalah negara-negara bekas kerajaan Islam, di mana tradisi perbudakan adalah bagian dari kultur kerajaan tersebut. Profesi pembantu rumah tangga (PRT) dipilih karena tidak membutuhkan skil, dan umumnya perempuan dewasa mampu melakukan hal tersebut.

Fase Migrasi dan Faktor Pendorong Perempuan Sasak Menjadi Buruh Migran

Gelombang pertama migrasi suku Sasak keluar negeri dapat dilacak dari aktivitas pendidikan para siswa asal Lombok di akhir abad ke 19. Tuan guru Umar Kelayu dan Tuan Guru Ali Batu berangkat ke Mekah di akhir abad ke 19, sedangkan Tuan Guru Muhammad Zainuddin Abdul Majid (pendiri Nahdlatul Wathan) dan Tuan Guru Saleh Hambali berangkat di awal abad ke 20. Selain motivasi pendidikan, mereka juga termotivasi untuk melaksanakan ibadah haji. Mereka berlayar dari pelabuhan Haji Lombok Timur menuju Mekah dengan jarak tempuh 3 bulan. Migrasi pendidikan ke Arab Saudi ini terus berkembang pada awal abad ke 20 hingga abad ke 21. Mereka tersebar di Madrasah Shaulatiyah, dan madarasah Darul Ulum di Mekah. Selain ke Mekah, kaum intelektual Sasak juga belajar ke Mesir, Yaman, Yordania, Irak, Iran dan Syuriah. Sepulang belajar dari Timur Tengah sebagian besar dari mereka berprofesi sebagai guru agama dan kyai (tuan guru).

Migrasi gelombang kedua pada tahun 1980, migrasi terkait dengan ketenagakerjaan yang merupakan program lanjutan oleh pemerintah Indonesia. Program ini dikenal dengan transimigrasi yang bermula didesain oleh pemerintah kolonial pada dan dilanjutkan oleh presiden Sukarno dan Suharto. Presiden Suharto mengirim transmigran ke Kalimantan, Sulawesi, Sumatera, dan Papua. Diperkiranan sebanyak 150.000 lebih masyarakat Sasak mengikuti program transmigrasi ke berbagai daerah. Di Kaltimantan Timur, jumlah warga Sasak diperkirakan sekitar 60.000 ribu orag dari 5.000.000 juta penduduk. Gelombang kedua ini juga ditandai dengan migrasinya masyarakat Sasak ke Malaysia. Menurut Haris (2002) pristiwa gagal panen dan tingginya tingkat pengangguran di Lombok mendorong masyarakat Sasak bekerja di Malaysia. Mereka ke Malaysia menempuh 
Tantangan Migrasi, Pengelolaan Remitansi, dan Kekerasan Terhadap Buruh Migran Perempuan Asal Lombok di Malaysia dan Arab Saudi

jalan ilegal karena Malaysia belum menerima tenaga kerja asing dan dinilai lebih murah.

Gelombang ketiga adalah pasca reformasi 1998 yang ditandai dengan krisis ekonomi di seluruh Indonesia. Kaum perempuan Indonesia termasuk perempuan Sasak semakin terjepit dengan keadaan di daerah yang minim lapangan pekerjaan. Pada saat bersamaan suami mereka banyak yang tidak berhasil di Malaysia. Data di lapangan menunjukkan bahwa migrasi perempuan Sasak ke Malaysia dimulai sekitar awal tahun 1990an. Sedangkan ke Arab Saudi dimulai sejak tahun 1995 dengan biaya transportasi 1 juta. Jumlah TKW Sasak mengalami puncak pasca reformasi 1998 yang ditandai dengan kebebasan media dan arus informasi. Bahkan di tahun 2000an, perempuan Sasak yang bekerja di sektor rumah tangga mendapat kemudahan dengan tidak membayar speserpun uang transportasi. Majikan di negara tujuan telah menanggung seluruh biaya termasuk fee kepada pemerintah Indonesia yang menyediakan jasa tenaga kerja. Akan tetapi pola ini tetap saja menjadi preseden buruk bagi TKW karena diperlakukan seperti budak oleh majikan. Mereka bekerja tidak kenal waktu dan seringkali mengalami kekerasan.

Adapun faktor-faktor yang menyebabkan migrasi perempuan Sasak adalah,

1. Krisis Ekonomi Keluarga

Krisis ekonomi yang dialami internal keluarga merupakan faktor utama pendorong perempuan Sasak ikut bermigrasi. Perempuan Sasak tidak ingin menambah beban keluarga mereka yang mengalami krisis dan kesulitan ekonomi. Selama ini perempuan dalam tradisi Sasak ditanggung dan dipelihara oleh keluarga terutama saudara laki-lakinya. Bahkan ketika menjadi janda, perempuan Sasak akan pulang ke rumah keluarganya. Jika orangtuanya meninggal dia akan menjadi tanggungan bagi kakak atau adik laki-lakinya. Perubahan ekonomi keluarga yang tidak selalu stabil, bahkan mengalami krisis yang berkepanjangan memotivasi perempuan Sasak untuk membantu keluarganya. Tidak banyak pilihan bagi perempuan Sasak selain ikut bermigrasi mencari pekerjaan tetap untuk membiayai dirinya dan keluarganya. Perempuan hanya menyiapkan makanan pada saat suami atau orangtuanya bekerja di lahan pertanian. 


\section{Keretakan Rumah Tangga}

Keretakan rumah tangga yang terjadi dalam keluarga Sasak menjadi salah satu faktor yang mendorong terjadinya migrasi perempuan Sasak. Setelah menikah di usia muda dan berstatus janda, gadis-gadis Sasak tidak memiliki banyak pilihan selain keluar negeri mencari pekerjaan. Kultur Sasak yang memudahkan perceraian tanpa proses pengadilan menempatkan perempuan pada posisi subordinat, dimana mereka tidak memiliki perlindungan hukum yang kuat. Perempuan Sasak dibebankan mengasuh dan membiayai anak-anak mereka tanpa kontribusi dari mantan suami. Mereka juga tidak memperoleh harta gono-gini, hanya dipulangkan ke rumah orangtuanya. Keretakan rumah tangga inilah yang membuat perrempuan Sasak dalam tekanan psikologis dan ekonomis membesarkan anak-anaknya. Mereka memilih mencari pekerjaan lain untuk menghibur dirinya dan membesarkan anakanaknya dengan menjadi TKW di Malaysia, Brunei, Singapura, Taiwan, Korea Selatan dan Arab Saudi.

Maemunah (43 tahun) asal Lombok Timur menikah diusia 17 tahun dan baru memiliki satu anak. Belum genap 7 bulan anaknya, tiba-tiba suaminya menikah secara diam-diam. Di tengah sakit hati dan rasa frustasinya, dia kemudian memutuskan untuk menjadi TKW ke Arab Saudi meninggalkan anaknya yang masih bayi. Dia berangkat pada tahun 1998 melalui sponsor H. Sofiani dari Suralaga Lombok Timur. Dengan berat hati dia meninggalkan anaknya yang masih berusia 7 bulan. Dia tidak berpikir panjang berangkat ke Saudi Arabia karena tidak ingin membebani keluarganya dan sebaliknya ingin membantu ekonomi orangtuanya.

Nuriati (30 tahun) memilih menjadi TKW setelah bercerai dengan suaminya yang kawin ketika menjadi TKI di Arab Saudi. Nuriati tidak menyangka suaminya yang bekerja sebagai TKI di Arab Saudi rela meninggalkan dirinya menikah dengan TKW lain di Arab Saudi. Nur menceritakan bagaimana sakit hatinya melihat fotofoto perkawinan suaminya yang dishare difacebook oleh istri baru suaminya. Dia juga mengancam Nuriati untuk meninggalkan suaminya dengan ikhlas. Setelah suami dan istri barunya habis kontrak dan pulang ke kampung, perkelahian tidak dapat dihindari dan Nuriati meminta cerai. Tidak tahan melihat suaminya yang 
Tantangan Migrasi, Pengelolaan Remitansi, dan Kekerasan Terhadap Buruh Migran Perempuan Asal Lombok di Malaysia dan Arab Saudi

masih saudara dan tinggal satu kampung dengan istrinya barunya, dia memilih untuk pergi sebagai TKW ke Abu Dabi. Rohmi (50 tahun) menceritakan keputusannya ke Malaysia pada tahun 1998 setelah suaminya meninggal. Rohmi pada waktu itu berumur 20 tahun dengan dua anak kebingungan membiayai anaknya yang masih kecil. Diapun bekerja keluar negeri dan bernasib baik di Malaysia karena dapat majikan yang bagus dan gaji yang cukup. Selain dapat memenuhi kebutuhan anak-anaknya, dia juga dapat membeli pekarangan dan sawah dari hasil keringatnya.

\section{Pendidikan dan Pengangguran}

Pendidikan yang rendah juga menjadi faktor pendorong perempuan Sasak bermigrasi ke luar negeri. Karena tidak mampu bersaing di kampung halaman dalam hal pekerjaan mendorong perempuan Sasak menjadi TKW. Daripada tidak ada pekerjaan di rumah dan membebani orang tua, mereka realistis bekerja keluar negeri dengan modal tenaga dan keahlian memasak. Hariati (42 tahun) menghabiskan masa mudanya ke Arab Saudi sebagai buruh migran. Usianya pada waktu itu relatif muda 15 tahun dan baru menyelesaikan sekolah tingkat pertama (SMP) diajak oleh temannya bekerja ke Arab Saudi di tahun 1995 melalui tekong dari Suralaga Mamiq Agus. Dia diajak oleh bibinya yang bekerja di kota Jeddah untuk berangkat daripada tidak ada pekerjaan di rumah dan membebani orang tua. Kondisi keluarga yang serba kekurangan dan banyaknya jumlah saudaranya 5 orang menjadi keperihatinan dan pertimbangan tersendiri bagi Hariati. Dia ingin adikadiknya kuliah di kampus yang bagus dan punya masa depan.

Umrati (35 tahun) memiliki cerita yang sama, meskipun dari keluarga yang berkecukupan, dia ingin menjadi perempuan mandiri yang tidak membebani orang tua. Meski diminta kuliah sama orang tua setelah tamat SMA, tapi dia tidak mau dan ingin mencari pengalaman bekerja di luar negeri. Dia diam-diam berangkat ke Arab Saudi dengan biaya yang pinjaman dari kakak iparnya. Dia hanya pamit sama ibunya, bapaknya sangat marah mendengar informasi tersebut. Laduniah (36 tahun) perempuan desa yang tamat SD dari keluarga terbelakang memberanikan diri kerja di luar negeri di usia 15 tahun. Dia masih tinggal di Arab Saudi dan menikah dengan orang lokal disana. Sumiati (43 tahun) juga memutuskan ke Mekkah untuk 
bekerja di sana. Dia ingin mengubah nasib keluarganya yang sangat kesultian secara ekonomi.

\section{Resistensi Budaya Lokal}

Gerakan menjadi buruh migran adalah bentuk perlawanan kaum perempuan Sasak terhadap praktik kebudayaan dan adat yang mengekang dan membatasi aktivitas mereka. Perempuan menghadapi dua sisi kehidupan yakni sangat dihormati, namun mereka juga dikekang tidak boleh bekerja di luar daerah, apalagi di luar negeri. Praktik kebudayaan Sasak yang menekan kaum perempuan mengalami titik balik resistensi yang kuat sehingga muncul "lompatan yang jauh". Dulunya mereka tidak boleh bekerja di luar kampung, sekarang mereka berlombalomba keluar negeri sebagai buruh migran. Gerakan mereka telah menggeser konstruksi gender yang sebelumnya menempatkan laki-laki di atas segalanya termasuk mengambil alih peran dalam mencari nafkah untuk keluarga. Di tengah kemandulan dan ketidakproduktifan laki-laki mencari nafkah, perempuan Sasak mengambil alih peran tersebut bahkan tidak sedikit yang berhasil melebihi produktifitas laki-laki. Perempuan Sasak dapat menabung hasil kerjanya dan mengirim remitansi secara utuh.

\section{Alasan Keagamaan}

Motivasi keagamaan juga sebagai faktor utama dalam proses migrasi perempuan Sasak. Sebagaian besar TKW yang bekerja di Arab Saudi tidak hanya bertujuan memenuhi kebutuhan ekonomi keluarga, tetapi juga mencari kesempatan melaksanakan ibadah haji. Mereka rela menjual atau menggadaikan sawahnya untuk biaya transportasi, yang penting mereka ditempatkan di seputar kota Mekah supaya dapat menunaikan ibadah haji. Indah (48 tahun), salah satu TKW asal desa Gapuk Suralaga menyatakan bahwa keberangkatannya karena doanya yang ingin menunaikan ibadah haji. Dia selalu berdoa "jika ditempatkan di dekat kota Makkah maka lapangkan jalannya sebagai buruh migran, apabila jauh dari kota Mekah maka tutupi jalannya". Doanya ini ternyata berhasil dan dikabulkan oleh Allah, dia ditempatkan bekerja beberapa kilo dari lokasi masjidil Haram. Majikannya memberi kesempatan untuk berhaji dua kali dan umrah berkali-kali. Sumiarti (41 tahun) telah lama bekerja di Qatar selama 20 tahun dan berkali-kali melakukan ibadah haji dari 
Tantangan Migrasi, Pengelolaan Remitansi, dan Kekerasan Terhadap Buruh Migran Perempuan Asal Lombok di Malaysia dan Arab Saudi

tempatnya kerjanya. Karena tidak puas dengan haji dari tempat bekerja, keluarga mendaftarkan dirinya naik haji dari Lombok biar masyarakat dan keluarga menyaksikannya. Keluarganya sangat bangga melihat anaknya berhasil, lebih-lebih menunaikan haji dari kampung halaman.

\section{Remitansi dan Penyalahgunaanya}

Remitansi adalah tindakan mentransfer uang oleh pekerja asing di negara tempat bekerja ke seseorang di negara mereka sendiri. Remitansi yang dilakukan oleh buruh migran dengan bantuan jasa keuangan internasional mejadi salah satu arus keuangan terbesar ke negara-negara berkembang dan menjadi modal penting khususnya negara pengekspor tenaga kerja (Bal \& Gerard, 2017: 8-9). Pada tahun 2014 terdaat $\$ 436$ milliar uang terkirim ke negara berkembang. Sedangkan secara keseluruhan remitansi global mencapai jumlah $\$ 582$ miliar di tahun 2015. Beberapa negara seperti India dan China menerima remitansi sebanyak \$10 miliar setiap tahunnya dari ekspatriat dan diaspora warga mereka ke berbagai negara. Pada tahun 2014 negara India menerima \$70 miliar dan China menerima \$64 miliar.

Menurut laporan World Bank Group's Global Knowledge Patnership on Migration and Develipment Initiative bahwa negara Indonesia menempati posisi 14 dunia menerima remitansi migran di tahun 2015 yang diperkirakan mencapai $\$ 10.5$ miliar dikirim dari tempat bekerja di luar negeri. Remitansi terus mengalir ke Indonesia dan menunjukkan peningkatan yang signifikan yakni $22 \%$ sejak tahun 2015, ketika itu mencapai $\$ 8.55$ miliar. Yang terbesar masih dipegang India $\$ 72.2$ milair, China \$63.9 milair, Amerika \$56, Arab Saudi \$37, Rusia \$33, Filipina \$29.7 miliar, Mexico \$25.7 dan Francis 24.6 miliar.

Provinsi Nusa Tenggara Barat juga ketiban berkah remitansi yang mendongkrak pertumbuhan ekonomi daerah. Menurut data BPS, propinsi NTB disinyalir menerima remitansi sebesar 1.76 Triliun pada tahun 2016 yang dikirim melalui pos dan Bank Indonesia. Hingga bulan Maret 2017, remitansi TKI asal NTB mencapai Rp. 347,9 miliar. TKI NTB yang bekerja di Arab Saudi masih menjadi penyumbang remitansi terbesar mencapai Rp. 41 miliar, sedangkan Malaysia menyumbang Rp. 4 miliar, dan disusul Uni Emirat Arab Rp.3 miliar. Sisanya adalah kiriman dari Hingkong, Singapura, Brunei Darussalam yang 
berjumlah Rp.73 miliar. Dari tiga Kabupaten, Lombok Timur memperoleh remitansi terbesar dengan jumlah Rp. 67 miliar, disusul Lombok Tengah Rp. 62 miliar, Sumbawa Rp. 24 miliar dan Bima Rp. 2 miliar.

Moratorium pengiriman buruh migran yang dilakukan oleh pemerintah tidak mengurangi jumlah remitansi dari Arab Saudi. Besarnya remitansi disinyalir karena jumlah TKI dan TKW ilegal terus bertambah di Arab Saudi dan adanya pemutihan sebesar 50 ribu buruh migran ilegal. TKI ilegal masuk ke Arab Saudi dengan menggunakan visa umrah. Setelah umrah mereka tidak kembali lagi ke Indonesia, tetapi bersembunyi di kontrakan teman-teman mereka yang sebelumnya bermukim di Arab Saudi. Mereka hanya keluar pada waktu-waktu tertentu demi menghindari pemeriksaan dari pemerintah.

Gaji buruh migran perempuan memperoleh gaji yang berbeda-beda di setiap negara yaitu sekitar 2-4 juta. Gaji mereka dikirim ke suami atau orang tua di kampungnya. Hal yang seringkali menjadi masalah adalah pengelolaan remitansi yang tidak produktif, bahkan cenderung digunakan untuk kebutuhan konsumtif misalnya membeli speda motor atau biaya pernikahan adik. Dari hasil riset menunjukkan bahwa dana remitansi selain untuk biaya kebutuhan sehari-hari, juga digunakan untuk biaya pendidikan, pembelian sawah, membangun urmah, membeli speda motor dan barang elektronik yang lain. Sumarni (42 tahun) asal Lotim menyatakan bahwa dirinya bertahun-tahun bekerja di Arab Saudi menjadi tulang punggung ekonomi keluarga tidak dapat menyimpan hasilnya. Remitansi yang dia kirim untuk membiaya adek-adeknya dari SMA hingga perguruan tinggi. Adek pertamanya kuliah di Singaraja Bali, sedangkan yang ketiga dan keempat kuliah di Lombok.

Remitansi juga digunakan untuk membeli kebutuhan sekunder keluarga seperti sepeda motor. Rajib (19 tahun) menggunakan uang kiriman ibunya yang bekerja di Malaysia untuk membeli sepeda motor. Alasannya membeli sepeda motor adalah untuk kuliah adik-adiknya. Sayang sekali setelah menikmati punya motor yang harganya cukup mahal yakni Rp. 21.000.000, motornya hilang dicuri di rumahnya. Ibunya sangat sedih karena hasil keringatnya terbuang begitu saja. Nizar (20 tahun) menggunakan uang kiriman kakak perempuannya yang bekerja di Arab 
Tantangan Migrasi, Pengelolaan Remitansi, dan Kekerasan Terhadap Buruh Migran Perempuan Asal Lombok di Malaysia dan Arab Saudi

Saudi untuk membeli motor. Dia terpengaruh dengan teman-temannya yang lain yang telah punya motor. Sebagai adik yang paling disayangi kakaknya, seluruh kebutuhannya menjadi prioritas termasuk biaya kuliahnya dan pembelian motor.

Temuan lain di lapangan adalah remitansi digunakan untuk menikah lagi. Hamidi (40 tahun) yang ditinggal istrinya keluar negeri menikah lagi dengan perempuan lain tanpa sepengetahuan istrinya yang lama. Sedangkan gaji istri tetap dikirimkan kepada suaminya. Uang remitansi juga digunakan untuk menyumbang pembangunan masjid. Swadaya masyarakat untuk membangun Masjid seringkali dibebankan buruh migran meskipun mereka sedang di Malaysia. Mereka dikenakan kewajiban membayar sumbangan pembangunan yang telah disepakati oleh panitia.

\section{Reproduksi Kekerasan Terhadap Buruh Migran Perempuan}

Kekerasan tidak pernah sepi dari kehidupan buruh migran khusunya TKW Indonesia yang bekerja di Malaysia, Arab Saudi, Singapura dan negara Timur Tengah lainnya. Dalam konteks ini negara dapat dikatakan "gagal" dalam melindungi hak-hak mereka termasuk bekerja dengan aman dan nyaman, dan diperlakukan secara manusiawi. Undang-undang perlindungan buruh migran tidak maksimal menyentuh ruang-ruang kerja perempuan yang tersembunyi dan sulit terdeteksi karena tinggal di dalam rumah majikan. Sebagai pembantu rumah tangga para TKW tidak leluasa membangun relasi dan komunikasi dengan komunitas di sekitar mereka. Paspor mereka ditahan dan tidak difasilitasi alat komunikasi, bahkan komunikasi dengan keluargapun sangat dibatasi oleh majikan. Kondisi inilah yang membuat buruh perempuan seringkali menjadi sasaran kekerasan majikan ketika terjadi masalah selama bekerja.

Kekerasan yang terjadi pada buruh migran perempuan sangat bevariasi meliputi kekerasan fisik, verbal dan seksual. Di Malaysia kekerasan fisik lebih dominan terhadap TKW. Selain tidak digaji, kata-kata kasar dan hinaan terhadap buruh perempuan Indonesia sudah jamak terjadi. Kata-kata budak "Indone" adalah stigma negatif dan kekerasan simbolik terhadap buruh migran asal Indonesia. Buruh migran juga dipukul, disetrika dan diambil organnya ketika telah wafat. Di Arab Saudi, TKW mengalami kekerasan verbal dan seksual. Sebagian besar TKW mengalami percobaan pemerkosaan oleh majikan dan anak laki-lakinya. Bahkan 
banyak TKW Sasak terpaksa dideportasi setelah mengalami kehamilan akibat pemerkosaan.

Rahmana, TKW yang masih muda (19 tahun) menceritakan bahwa dia hendak diperkosa oleh anak majikannya. Malam-malam dua anak majikan mengetuk pintu dan mereka sudah dalam keadaan telanjang memegang alat kelaminnya. Dia kaget dan mengancam teriak jika mereka tidak berhenti. Karena tidak berhenti, dia berlari keluar menemui majikannya. Awalnya majikan perempuan tidak percaya dengan cerita tersebut dan mau menyalahkan dia atas kasus ini. Akan tetapi setelah mereka mengecek ke kamar anaknya dan menemukan masih dalam keadaan telanjang. Sadah, TKW yang telah lanjut usia (47 tahun) juga mengalami percobaan pemerkosaan. Anak majikannya melakukan percobaan pemerkosaan, akan tetapi Sadah mengancam akan melaporkan polisi. Karena berani melawan, Sadah selamat dari pemerkosaan dan majikannya minta maaf dan menawarkan jika dia siap dikawinkan dengan anaknya walaupun lebih muda. Sadah ingat anak-anaknya di kampung halaman yang masih kecil dan sedang kuliah. Dia menolak tawaran untuk menikah dengan anak majikan yang masih muda. Dia menceritakan anak majikannya tertarik karena dia rajin beribadah dan disiplin bekerja.

Lina (37 tahun), ibu muda dengan dua anak memberanikan diri menjadi TKW ke Arab Saudi. Dia tergiur dengan jumlah gaji yang menjanjikan, apalagi tidak dipunguti biaya selama pemberangkatannya. Dia minta izin ke suami untuk bekerja di Arab Saudi karena alasan ekonomi keluarga yang tidak kunjung membaik meskipun suaminya bolak-balek sebagai buruh migran ke Malaysia. Di awal-awal bekerja, Lina selalu mengirim uang gaji kepada suami dan anak-anaknya yang masih sekolah SD. Gajinya sekitar 4.000 .000 perbulan yang dibayar 3 kali sebulan. Di tahun kedua, dia memutuskan pindah bekerja karna gajinya mulai dipersulit dan adanya persoalan dengan majikan. Dia kemudian pindah tempat kerja, dia dibantu oleh teman-teman TKI yang lain di dalam taxi. Waktu diantar ke hotel dia tidak sadarkan diri dan menelpon suami jika dia ingin pulang karena alasan sakit. Suaminya bahagia dengan kepulangannya ke rumah. 
Tantangan Migrasi, Pengelolaan Remitansi, dan Kekerasan Terhadap Buruh Migran Perempuan Asal Lombok di Malaysia dan Arab Saudi

Lina mulai rutin berobat karena dia merasa sakit di perutnya. Setelah keliling dengan pengobatan alternatif perutnya tidak sembuh dan terus membesar. Warga mulai menaruh curiga, jika dia hamil. Ibu-ibu di kampungnya khususnya keluarga suami mulai mengintrogasinya dengan pelan-pelan, akan tetapi dia tetap tidak mengakui jika dia sedang hamil. Dia menyatakan, tidak pernah bersetubuh dengan laki-laki bagaimana dia bisa hamil. Kepala Dusun yang masih keluarga berinisiatif membawanya ke Puskesmas terdekat untuk diperiksa dan hasilnya dinyatakan positif hamil. Dia dirujuk ke rumah sakit karena ketubannya sudah pecah dan harus melahirkan segera. Setelah melahirkan, keluarga suaminya protes dan memberikan pilihan kepada suaminya untuk bercerai atau keluar dari keluarga. Suaminya kemudian memilih bercerai dan anak-anaknya yang lain tinggal bersama suaminya. Lina dijemput keluarganya dengan rasa sedih yang luar biasa.

Rohimah, perempuan dengan satu anak yang bekerja di Arab Saudi tidak pernah digaji selama dua tahun. Dia kehilangan kontak dengan suami dan keluarganya di Lombok. Dia kemudian memutuskan lompat dari apartemen lantai 12 karena menghindari pemerkosaan. Keluarga Muhir (45) asal desa Beleke, Gerung, Lombok Barat mendapat kabar jika istrinya terbaring sakit di rumah sakit. Joharni mengalami kekerasan selama menjadi TKW di Arab Saudi. Selama satu tahun suami tidak mendengar kabar dari Joharni dan tiba-tiba dapat SMS dari teman Joharni yang menyatakan dia sedang sakit. Dia sakit parah akibat siksaan majikannya. Dia telah bekerja sekitar dua tahun yang lalu melalui PT. Dasa Graha Utama dan belum pernah mengirim uang dari hasil keringatnya. Muhir hanya bisa berharap supaya istrinya cepat sembuh dan dipulangkan dalam keadaan selamat.

Muliati, TKW asal Dasan Baru, Lombok Barat berusaha lompat dari apartemen tempat bekerjanya di Riyadh dan mengalami patah tulang. Dia berupaya lompat menghindari aksi pemerkosaan oleh majikan. Keluarga yang mendengar itu tidak bisa tenang dan melaporkan ke pihak Pusat Bantuan Hukum Buruh Migran untuk dipulangkan. Menurut suami dan ibunya, Muliati selalu mengirim kabar kepada mereka dan seringkali kirim uang. Tiba-tiba mendengar ini mereka tidak bisa tidur nyenyak. Tidak hanya TKW yang mengalami kekerasan, TKI juga terlibat berbagai masalah. Fathul, TKI asal Lombok Barat ditemukan tidak bernyawa 
setelah ditembak oleh keluarga tempat bekerja di daerah Tabuk. Fathul, pekerja sebagai sopir ditengarai berkelahi dengan keluarga majikan. Meskipun keluarga Fathul telah memaafkan pelaku, akan tetapi mereka meminta keadilah supaya diberikan uang denda sekitar 1.5 M. Mereka memperjuangkan kasus ini ke Gubernur NTB untuk diteruskan ke pusat. Tidak adil jika hanya TKW yang dihukum Pancung atau bayar denda, majikan di Arab juga harus bayar denda apabila melanggar hukum.

Peristiwa-peristiwa di atas menunjukkan bahwa kekerasan terhadap buruh migran perempuan terus mengalami reproduksi. Mereka mengalami kekerasan yang sulit dipantau oleh pemerintah karena mereka tinggal di rumah majikan, sedangkan mereka sangat dibatasi komunikasinya dengan orang lain termasuk keluarga. Para TKW tidak memiliki agensi, hidup mereka dikontrol secara penuh oleh majikan. Mereka seperti hidup dalam penjara dengan penyiksaan yang luar biasa. Praktikpraktik perbudakan sulit dihindari, mereka diperlakukan seperti budak dengan bekerja tanpa batasan waktu yang jelas dan menerima kekerasan tanpa perlawanan kepada majikan. Kasus ini semakin meningkat dari hari ke hari, pemerintah harus melakukan intervensi kebijakan guna mengatasi masalah ini.

\section{Kesimpulan}

Buruh migran perempuan mengalami berbagai persoalan sosial kebudayaan ketika bekerja di lingkungan yang berbeda. Perbedaan bahasa dan budaya sangat mempengaruhi pola komunikasi antara TKW dan majikan. Tidak sedikit hanya karena faktor komunikasi TKW seringkali ditimpa kekerasan oleh majikan. Sementara pemerintah tidak memiliki akses memantau kehidupan mereka seharihari karena TKW tinggal bersama keluarga yang privasinya sangat terjaga. Pada saat yang bersamaa TKW tidak memiliki akses dan alat komunikasi karena aturan di dalam keluarga tersebut yang membatasi mereka. Menelpon keluarga saja sulit dan dibatasi, apalagi melaporkan kepada pihak yang berwajib. Kondisi ini membuat mereka terancam dan rawan kekerasan termasuk pemerkosaan yang dilakukan oleh majikan. Bahkan, banyak diantara mereka yang tidak memperoleh gaji sesuai dengan kontrak perjanjian sebelumnya. Proses TKW dapat dikatakan sebagai proses 
Tantangan Migrasi, Pengelolaan Remitansi, dan Kekerasan Terhadap Buruh Migran Perempuan Asal Lombok di Malaysia dan Arab Saudi

"perbudakan modern" karena banyaknya ketidakadilan, diskriminasi dan kekerasan yang menimpa mereka.

Kekerasan terhadap TKW terus terjadi baik yang bersifat fisik maupun seksual. Kasus kekerasan, pemerkosaan dan penundaan gaji adalah bagian dari kehidupan TKW yang belum dapat dipecahkan dan dintervensi oleh pemerintah. Apabila tidak ada perlindungan yang serius maka dapat dipastikan para TKW akan mengalami reproduksi kekerasan. TKW tidak hanya menyerahkan kehormatan mereka, tetapi juga nyawa mereka yang menjadi taruhan. Mereka tidak lagi diperlakukan secara manusiawi, kebebasan dan kemerdekaan mereka disandera oleh majikan.

Tidak semua TKW mengalami kegagalan, dan sebaliknya sebagian juga berhasil. Mereka memperoleh majikan yang baik dan tentunya gaji mereka juga lancar. Di level keluarga dan negara TKW memainkan peran penting dalam pembangunan ekonomi. Mereka terbukti mampu menyumbang remintasi yang sangat tinggi sehingga secara tidak langsung menyumbang peningkatan devisa negara. Remitansi TKI secara nasional dalam setahun mencapai 10 Triliun, sedangkan NTB mencapai 1.7 Triliun. Jumlah angka remitansi ini sangat fantastis di mana Indonesia berada diperingkat 14 dari seluruh dunia. Yang menjadi persoalan adalah penggunaan remitansi yang belum maksimal karena lebih bayak digunakan untuk kepbutuhan skunder. Banyak TKW yang tidak dapat memenage keuangannya sehingga mereka harus kembali lagi ke negara tujuan untuk bekerja menjadi buruh migran. Bahkan terdapat TKW yang menghabiskan separuh dari kehidupannya menjadi buruh migran.

\section{Daftar Pustaka}

Ardiansyah, S. (2007). Policy Brief on Bilateral Labor Agreement of Indonesian. Institute for National and Democratic Studies (INDIES) Indonesia 1-12.

Asriani, D.D dan Amalia, E. (2014). Jejak Perempuan Buruh Migran dalam Masyarakat ASEAN 2015. Jurnal Ilmu Sosial dan Ilmu Politik, 18(2), $147-$ 159.

Azmy, A.S. (2012). Negara dan Buruh Migran Perempuan: Menelaah Kebijkan Perlindungan Masa Pemerintahn Susilo Bambang Yudoyono 2004-2010. Jakarta: Yayyasan Pustaka Obor Indonesia.

Bal, C.S, dan Gerard, K. (2017). ASEAN's governance of migrant worker rights. 
Third World Quarterly, https://doi.org/10.1080/01436597.2017.1387478.

BPS NTB. (2018). Provinsi Nusa Tenggara Barat Dalam Angka 2018. Pemprop NTB.

BPS NTB. (2015). Provinsi Nusa Tenggara Barat Dalam Angka 2015. Pemprop NTB.

Chin, C.B.N. (1997). Walls of Silence and Late Twentieth Century Representations of the Foreign Female Domestic Worker: The Case of Filipina and Indonesian Female Servants in Malaysia. IMR, 31(2), 353-385.

Constable, N. (2009). Migrant Workers and the Many States of Protest in Hong Kong. Critical Asian Studies. 41(1) 143-164., https://doi.org/10.1080/14672710802631202

Greenwood, M. J., \& Hunt, G. L. (2003). The Early History of Migration Research. International Regional Science Review, 26(1), https://doi.org/10.1177/0160017602238983

Haryani, R. N., Indonesia, D., \& Buruh, D. (2011). Tinjauan Kriminologi Kritis terhadap Kebijakan Negara dalam Melindungi Perempuan Buruh Migran Pekerja Rumah Tangga. Jurnal Kriminologi Indonesia. 7(2), 174-192.

Hakim, L, Fitrianto, A. (2015_. Political Economy of Sending Domestic Workers Abroad: Case Study of Indonesian Migrant Workers. Mediterranean Journal of Social Science, .6(4).

Karim, M. F. (2017). Institutional Dynamics of Regulatory Actors in the Recruitment of Migrant Workers. Asian Journal of Social Science, 45, 440464. https://doi.org/10.1163/15685314-04504004

Kaur, A. (2009). Labor Crossings in Southeast Asia: Linking Historical and Contemporary Labor Migration. New Zealand Journal of Asian Studies. 11 (1), 276-303.

........... (2014). Mobility, Labour Mobilisation And Border Controls: Indonesian Labour Migration To Malaysia Since 1900. Paper ini dipresentasikan pada seminar "15th Biennial Conference of the Asian Studies Association of Australia" di Canberra 29 June-2 July 2004.

Killias, O. (2010). 'Illegal' Migration as Resistance: Legality, Morality and Coercion in Indonesian Domestic Worker Migration to Malaysia. Asian Journal of Social Science, 38, 897-914, https://doi.org/10.1163/156853110X530796

Larsen, J. J. (2010). Migration and people trafficking in southeast Asia. Trends \& issues in Crime and Criminal Justice. 401.

Maksum, A., dan Surwandono. (2017). Suffer to Survive: The Indonesian Ilegal Workers Experiences in Malaysia and Japan. Journal of Social Research \& Policy, 8(1), 1-23.

Melchert, P. (2017). Indonesian Migrants in Taiwan: Religion and Life-style. Arbeitspapiere zur Ethnologie, Working Papers in Social Anthropology, (4)

Hermawan, Y.P dkk. (2014). Identifikasi Potensi Perempuan dalam Upaya Perlindungan Buruh Migran Perempuan Indonesia. Laporan Hasil Penelitian: Lembaga Penelitian dan Pengabdian kepada Masyarakat Universitas Katolik Parahyangan.

Pels, P. (1997). The Anthropology of Colonialism: Culture, History, and the Emergence of Western Governmentality. Annual Reviews of An Anthropology, 
Tantangan Migrasi, Pengelolaan Remitansi, dan Kekerasan Terhadap Buruh Migran Perempuan Asal Lombok di Malaysia dan Arab Saudi

26, 163-183.

Sakdapolrak, P. (2002). Ringkasan Eksekutif Perlindungan Buruh Migran Perempuan: Kebijakan di Negara-negara Pengirim dan Penerima, Jakarta: Internship in IDF Grant

Human Rights Watch, (2004). Help Wanted: Abuses against Female Migrant Domestic Workers in Indonesia and Malaysia. Human Rights Watch,16(9).

Putra, P. (2019). Strategi dan Informasi Transmigrasi pada Masa Orde Baru dalam Rangka Mensukseskan Program Pembangunan Nasional. Jurnal Kepustakawanan dan Masyarakat Membaca, 35 (2), 1-15.

Rahman, M., dan Fee, L. K. (2009). Indonesian Domestic Workers in Hong Kong, Singapore and Malaysia. 5(2). https://doi.org/10.1080/17441730902992059

Rahmat, A. et al. (2018). Dari Imigrasi Menuju Integrasi: Peranan Etnis Jawa Dalam Politik Di Suriname (1991- 2015). FACTUM: Jurnal Sejarah Dan Pendidikan Sejarah, 7(1). https://doi.org/10.17509/factum.v7i1.11923

Rother, S. \& Rother, S. (2017). Indonesian migrant domestic workers in transnational political spaces : agency, gender roles and social class formation formation. Journal of Ethnic and Migration Studies, https://doi.org/10.1080/1369183X.2016.1274567

Sulistiyo, P.A., dan Wahyuni, E.S (2012). Buruh Migran Perempuan Dalam Rumahtangga. Sodality: Jurnal Sosiologi Pedesaan, 06(03), 252-258.

Scott, D. (1992). Anthropology and Colonial Discourse: Aspects of the Demonological Construction of Sinhala Cultural Practice. Cultural Anthropology, 7(3), 301-326. https://doi.org/10.1525/can.1992.7.3.02a00020

Silvey, R. (2004). Transnational Migration And The Gender Politics Of Scale: Indonesian Domestic Workers In Saudi Arabia. Singapore Journal of Tropical Geography, 25(2), 2004, 141-155.

........... (2007). Mobilizing Piety: Gendered Morality and Indonesian -Saudi Transnational Migration. Mobilities, 2 (2), 219-229, DOI: 10.1080/17450100701381565.

Surtees, R. (2003). Female Migration and Trafficking in Women: The Indonesian context. Development 46(3), 99-106.

Susanti, S. (2016). Nasionalisme Dan Gerakan Mulih Njowo, 1947 Dan 1954. Jurnal Sejarah Citra Lekha, 1(2), https://doi.org/10.14710/jscl.v1i2.12767

Wickramasekera, P. (2002). Asian Labour Migration: Issues and Challenges in an Era of Globalization. Laporan dan Kesimulan: ILO Asia-Pacific Regional Symposium for Trade Union Organizations on Migrant Workers, 6-8 December 1999, Kuala Lumpur, Malaysia, ILO. Bangkok, International Labour Office: Bureau of Workers Activities. 